\title{
Introduction: situating gender scholarship in IPE
}

\author{
Juanita Elias and Adrienne Roberts
}

This collection marks an effort to showcase the wide-ranging scholarship that has come to constitute the study of gender and International Political Economy (IPE). The publication of a handbook of this nature marks an important point in the development of the field of gender and IPE. In recent years, feminist scholars working in and around IPE have made some important efforts to raise the status and standing of genderfocused work. This has resulted in a number of journal special issues (Bedford and Rai 2010; Steans and Tepe 2010; Shepherd and Ferguson 2011; Bernstein 2014; Elias 2015; Elias and Roberts 2016; Ferguson et al. 2016; Tepe-Belfrage and Wallin 2016), edited collections (e.g., Bezanson and Luxton 2006; Bakker and Silvey 2008; Rai and Waylen 2013; Hozic and True 2016), conference panels and workshops, and single authored manuscripts. ${ }^{1}$ In part these efforts stem from the continued frustrations that many feminists have had as they see both mainstream and critical IPE scholars finding it easy to ignore and/or sideline the contributions of feminist work (Tickner 1991; Waylen 2006; Elias 2011). Although most IPE textbooks now contain some discussion of gender issues and feminist research, feminist scholarship has been rendered invisible in some of the more influential efforts to chart the field of IPE - notably in Cohen's International Political Economy: An Intellectual History (2008) and in Blyth's Routledge Handbook of International Political Economy (2009). It would appear to frequently be the case that gender scholarship is easily sidelined by the disciplinary 'malestream'.

The disregarding of gender scholarship, when and where it occurs, is surprising given that this research has flourished in recent decades. A key objective of this volume is therefore to draw attention to the continued rise and development of gender approaches to IPE. Nonetheless, while we seek to centralize recent contributions to gender IPE scholarship, highlighting new empirical foci, innovative theoretical engagements across disciplines and novel methods of analysis, we are also well aware that feminist IPE is not entirely coherent, nor is it particularly new. Rather than telling a single, universal and linear 'feminist story' (Hemmings 2011) about the rise of the body of scholarship that we refer to here as 'Feminist IPE', we see this Handbook as an opportunity to highlight and celebrate its multiple and diverse roots and influences. Indeed, an appreciation of such diversity is central to the development of this project as one in which no singular, or straightforward, way of 'doing' feminist IPE is put forward. While it is certainly the case that for many scholars and teachers of IPE, gender approaches are simply not recognized at all, we also note a tendency even within more critical IPE work to adopt a 'week on'/'chapter on' gender approach whereby feminist and/or gendered scholarship is usually characterised as work that simply provides an analysis of the impacts of globalization on women. ${ }^{2}$ Absent here is any sort of critical reflection on the multiple and varied traditions of feminist political 


\section{Handbook on the international political economy of gender}

economy scholarship and wider debates within feminist theory more generally (e.g., over the very understanding of the concept of gender; see Nicholson 1994; Zalewski 2000).

In observing the multiple roots and influences on feminist IPE one might point to, for example, established (and at times conflicting) traditions of feminist scholarship that have looked to understand the political-economic foundations of gender-based oppressions - especially that found in Marxist/socialist feminist thought (e.g., Hartmann 1979; Vogel 1983) and some traditions of Black feminist scholarship (e.g., Davis 1981; hooks 2000). Feminist sociologists and anthropologists offered some of the first analyses of how historically and culturally specific forms of social reproduction shape and are shaped by gender relations, and how they intersect with broader macrohistorical processes (Edholm et al. 1978; Laslett and Brenner 1989). A key influence also comes from work in feminist economics that serves to question the foundational assumptions of mainstream liberal economic thinking, such as assumptions about 'rational economic man' and the undervaluing of care (e.g., Ferber and Nelson 1993; Folbre 1995). Important too has been the recognition in gender and development scholarship of the centrality of gender relations to the politics and practice of international development (see Rai in this volume; Sen and Grown 1987; Kabeer 1994; Marchand and Parpart 1995; Jackson and Pearson 1998) and work that highlights the importance of generating transnational feminist solidarities in order to challenge and resist the gender inequities that stem from capitalist globalization (as well as the difficulties and challenges of forging such solidarities) (Mohanty 2003; Moghadam 2005; Salem 2018). A concern with how the functioning of the global economic system impacts women, and how it was itself constituted by gender relations, further emerged in a number of feminist International Relations (IR) texts from the late 1980s onwards (Enloe 1989; Pettman 1996; Peterson and Runyan 1999; Steans 2013).

While some IPE scholarship, including some feminist IPE scholarship, sees itself as being a particular field of research within the broader discipline of IR, the vast array of intellectual influences that are highlighted in the chapters of this volume suggest a much more diffuse intellectual endeavour. ${ }^{3}$ Our understanding of the multidisciplinary origins of feminist IPE further marks a departure from several of the most well-known accounts of IPE, which present it as a relatively new area of study that is derived from political science, to which it brings insights from the discipline of economics (Murphy and Nelson 2001; Cohen 2007). It is partly due to this multidisciplinarity, we would argue, that feminist IPE has been able to avoid the problematic reifications of 'the political', 'the state' and the 'international' that plague so much non-feminist IPE scholarship.

\section{SOME REFLECTIONS ON ‘THE FIELD’ OF FEMINIST IPE}

During the 2000s feminist scholars sought to define the field of feminist IPE via a number of key interventions focused on development (Rai 2002), neoliberal restructuring (Bakker and Gill 2003; Bergeron 2003), globalization (Peterson 2003), and efforts to articulate what 'doing' gender and political economy was, along with its implications for the discipline (Cook et al. 2000). In the introduction to their seminal collection 
Gender and Global Restructuring, Marchand and Runyan (2000 [2011], p. 12) offer a characterization of feminist IPE that positions these agenda-setting texts as indicative of 'feminist re-sightings of global restructuring' (our emphasis). As such, it is worth outlining the frameworks advanced by some of these authors, who have offered alternative feminist narratives of the global political economy in all its complexity.

To begin, the theoretical sophistication and richness of feminist IPE scholarship is revealed in Peterson's (2003) work that draws upon understandings of both the cultural and the material underpinnings of global restructuring in demonstrating how gender in the global political economy works through various circuits of power, namely, the reproductive (R), productive $(\mathrm{P})$ and virtual $(\mathrm{V})$ economies. Her analytical framework, which she terms the 'RPV framing', calls for the identification of a wide range of global processes, as well as a theorization of their connections:

The 'RPV framing' brings the identities, ideologies, and practices of 'social reproduction,' welfare, non-wage labor and informalization into relation with the familiar but the now global and flexibilized 'productive economy' of goods and services, as well as with the less familiar but increasingly consequential - though dematerialized - 'virtual economy' of financial markets, cyberspace, and the exchange less of goods than of signs. (Peterson 2002, p. 1)

Furthermore, Peterson's analysis speaks directly to critical IPE scholarship, asking that scholars reflect on her theories 'illuminating race, gender, class and national hierarchies as structural features of neoliberal globalization' (2003, p. 173).

In their work, Bakker and Gill also call for 'a new conceptual framework and ontology of political economy' (2003, p. 14). Building on Robert Cox's (1987) influential Production, Power and World Order, Bakker and Gill establish a framework that seeks to identify how specific configurations of power, production and social reproduction must be understood together, as co-constitutive of world order, and as integral to the shaping of gender relations in both the symbolic and the material sense. They argue that neoliberal restructuring has entailed processes of, on the one hand, the re-privatization of social reproduction and, on the other, a 'general increase in the range, depth and scope of socioeconomic exploitation in global capitalism amid wider conditions of primitive or original accumulation' (2003, pp. 17-41). These processes, and their attendant effects on gender relations, are then explored at the mico, meso and macro levels, drawing attention to processes ranging from the reconstitution of the self along neoliberal lines to the inequitable distributional effects of neoliberal macroeconomic and fiscal policy.

While both of the frameworks outlined above identify some of the various ways in which states are involved in global restructuring, this is front and centre in Rai's (2002) Gender and the Political Economy of Development. This work connects gender and development scholarship to wider debates in IPE about the extent and nature of state restructuring under conditions of neoliberal globalization. Cautioning critics of globalization 'against nostalgia for the centralized nation-state' (2002, p. 199), Rai notes how the state has been central to the generation of forms of gender oppression. Rai sounded a warning that seems all the more apt today as states around the world have embarked on economic and social projects that have had profound impacts for women's freedoms and gender justice. 


\section{HANDBOOK STRUCTURE AND RATIONALE}

As the above characterization of the field indicates, our project is, by necessity, one of intellectual eclecticism. Rather than defining exactly what feminist IPE should be or should do, we allow each individual contribution to speak for itself, and invite reflection by the reader. In this introduction and throughout the chapters of this Handbook, we use the terms 'feminist approaches' and 'gender approaches' interchangeably. We understand these approaches to be ones that critically interrogate the ways in which gender operates as a relation of social power in different times and places. In contrast to those scholars who equate gender with women, and/or define gender solely in terms of an 'identity', the scholarship in this volume shows how gender operates as both a discourse and as a structural relation of inequality within the global political economy. While not all gender scholars readily identify as 'feminist', we believe that the research showcased in this collection all contributes to the feminist political project that seeks to understand and to challenge how the categories of 'masculine' and 'feminine' have been established and maintained, and to document and undermine the privileging of the former over the latter in different sites and spaces. We further understand the feminist project to be interested in understanding and challenging how different types of men and masculinities are valued differently, as are different types of women and femininities, as these gender power relations are further shaped by race, nationality, sexuality, class and more (Connell 1995). The point is not to suggest that there is a single 'feminist' political agenda, as several of the chapters point to historical and contemporary contestations between different feminist ideas and social forces (see, e.g., chapters by Gregoratti, Ferguson and Calkin), though we do see value in maintaining an explicit commitment to feminist praxis (i.e., the interconnections between feminist theory and practice).

We seek to embrace the current diversity of feminist IPE in three main ways. First, via the commissioning of chapters that look to very different feminist theoretical and methodological traditions that have informed the emergence of and development of feminist IPE. To us such an endeavour matters not least because of the persistent tendency to present feminist IPE as a coherent theoretical approach within IPE. Second, we aim to present as broad an empirical scope of feminist scholarship as possible mapping out broad fields of focus alongside particular issue areas. In terms of a diversity of fields, we survey, for instance, feminist institutionalism, queer theory, security studies, state theory and more. Some of the issue areas that are covered here, but likely to be overlooked by tokenistic overviews of feminist IPE, include postconflict violence against women, private security firms, remittances, alternative economies, regional development banks and the global prison. Finally, as outlined above, we see the development of feminist IPE as an interdisciplinary endeavour that takes us beyond established disciplinary boundaries.

Nonetheless, and as the chapters included in this volume demonstrate, we recognize that there is a coherence about what constitutes feminist research. Ackerly and True, for example, in their work on feminist methods set out the view that a critical feminist methodology involves, among other things, 'attentiveness to (1) unequal power relations, (2) to relationships, (3) to boundaries of inclusion-exclusion and forms of marginalization, and (4) situating the researcher in the research process' (Ackerly and 
True 2010, 2013, p. 136). While these broad concerns are the overarching methodological framework for critical feminist analysis, a whole range of methods can be deployed that help to reveal concealed and unequal power dynamics. Indeed, one of the things that makes much feminist IPE unique is its commitment to methodological pluralism, but with a common rooting in a framework that challenges the often unseen andocentric or masculine biases in the way that knowledge has traditionally been constructed in academia, in economics and other professions, and in policymaking circles.

Our aim is to showcase the diversity and dynamism of the field of feminist IPE, which we do via a chapter structure that highlights (1) theoretical diversity, (2) key engagements between feminist IPE and other traditions of scholarship, (3) the multiple ways in which gender informs and is produced by the governance of markets and economies, and (4) flows of people and things in the gendered global political economy. In what follows we offer an overview of each of the four parts of the Handbook.

\section{Part I: Theories and Approaches}

We begin this Handbook with a collection of chapters that provide theoretical and methodological reflections on the field of feminist IPE. This part of the Handbook makes for an intriguing collection of chapters which point to the multiple and diverse origins of and influences on feminist IPE including its influence within feminist International Relations (IR), its relationship to broader traditions of feminist political and social theory, and its unique methodological insights. For many feminist IPE scholars, it is social reproduction feminism that offers the greatest theoretical purchase in terms of the analytical importance it places on issues of material disadvantage and the gendered impacts of neoliberal globalization. Nonetheless, what is evident from a reading of the chapters in this part is that even work that ostensibly presents itself as social reproduction feminism also speaks to other traditions of feminist thought. It is inevitably then quite difficult to present in this part chapters that offer up theoretically 'pure' traditions of feminist IPE as a certain degree of intellectual eclecticism underpins much contemporary feminist IPE theorizing. What the chapters in this part serve to do, then, is to demonstrate how diverse traditions of feminist scholarship provide us with insights into how gender is performed, enacted, embodied, constructed, institutionalized and reconstituted in the global economy and how these processes work through other many and varied structures of oppression - including histories of colonialism, heterosexism and racism - and are in turn actively resisted.

We begin this part with a chapter that sets out some of the core challenges for feminist IPE scholarship. V. Spike Peterson's chapter is a provocation - moving beyond the plea that the fields of IR and IPE take gender more seriously (Tickner 1997; Steans 2003; Waylen 2006; Zalewski 2007; Elias 2011), Peterson seeks to expose the 'problematic premises' of IPE scholarship: positivism, modernism and masculism (PMM). These are premises that feminist IPE will often (unwittingly) internalize perhaps sometimes even knowingly - in the quest to have feminist work taken more 'seriously' by the 'malestream'. For Peterson, it is postcolonial and poststructuralist feminist work that best destabilizes these foundational assumptions (see also chapters 


\section{Handbook on the international political economy of gender}

by Griffin and Nair in this volume) - although most feminist IPE work does serve to raise key concerns about what the 'proper' study of IPE should be about, and challenges IPE scholars to take issues of the household/family, affect and subjectivities more seriously.

Meg Luxton's chapter on social reproduction feminism introduces an important body of work that has sought to demonstrate the centrality of socially necessary reproductive labour to the functioning of the productive economy. This Marxist-feminist insight has a particular relevance for contemporary discussions of neoliberal globalization exposing how state restructuring has been enabled via the increase in socially reproductive burdens to society's poorest. Hence, neoliberalism's success 'depends on individuals absorbing most of the costs of social reproduction so it has disproportionately negative impacts on women, especially as their responsibilities for social reproduction intensify'. This process can be seen as part of an emerging tension between capital accumulation and social reproduction (see also Bakker and Gill 2003) - a tension that is maintained via a 'racially structured global market in human labour power' that is supported by exclusionary citizenship practices and deeply discriminatory migration regimes (see also Arat-Koç in this volume).

Sheila Nair's chapter further considers the emergence of racialized markets under neoliberalism from the perspective of postcolonial feminism. For Nair, it is those postcolonial writings associated with the move toward decolonial theory that speaks most urgently to the core concerns of IPE - offering critiques of how IPE knowledge is produced, how IPE research is done and how best to understand the huge economic disparities that characterize the contemporary global order. This is an approach that 'underscores the nexus of imperialism, coloniality, race, sexuality and gender and conveys the significance of thinking through these intersections'. Such an approach, Nair suggests, enables a better appreciation of how conditions of oppression are sustained within the current global order: 'an international political economy that thrives on the subjugation and denigration of, and violence visited on, racialized, classed and sexualized bodies'.

As Peterson claims in her chapter, postcolonial feminism has made a significant and sustained impact on feminist IPE theorizing. Postcolonial feminism has of course also challenged feminist theory more generally - in particular the privileging of white Western elite women in first wave (liberal) feminist texts. The disputes between postcolonial and liberal feminism are taken up in more detail in Jane Jaquette's chapter. Jaquette's engagement with liberal feminism provides a useful restatement of a particular strand of liberal feminist political theory that nonetheless retains contemporary significance for feminist IPE scholars. As writers such as Zalewski suggest, it is important to recognize the continued influences and lineages of feminist theorizing and to be cautious about the tendency to think in terms of 'apparently opposing bodies of feminist thought' $(2000$, p. 1) in which whole traditions of thought associated with a particular feminist 'wave' can be so easily written off/fall out of fashion. ${ }^{4}$ Jaquette asks that we consider the place of a liberal feminist theory within IPE, for example, in terms of how we think about concepts such as democracy, human rights, equality and the public/private divide. Of particular interest is the liberal feminist critique of essentialized notions of household labour that often emerge in feminist writings on care suggesting that the pursuit of equality requires the complete eradication of the 
public/private divides that can only serve to sustain gender inequality. ${ }^{5}$ Nonetheless, Jaquette notes that there has been a failure on the part of most feminist liberal political theorists to develop an 'effective basis for responding to global capitalism'. Whether or not liberal feminism is up to the task of developing such a position certainly remains to be seen.

Gülay Çağlar and Penny Griffin's chapters are the two chapters in this part that respond most directly to current theoretical debates in the field of IPE more generally. Over the last two decades, constructivism has emerged as one of the major schools of IPE scholarship (a trend in line with IR scholarship more generally; see Jordan et al. 2009). The rise of constructivist IPE has created certain dilemmas for feminist IPE scholars - the emergence of a field of study emphasizing the social construction of intersubjective identities in global politics would appear at face value to be a field in which feminist perspectives are welcomed. And yet, constructivist IPE and feminist IPE have largely emerged as distinct traditions (with a couple of notable exceptions: Locher and Prügl 2001; Widmaier 2015). Çağlar suggests that although some feminist IPE scholarship is profoundly materialist in orientation, a feminist constructivism underpins a great deal of recent work on how we understand relations of production/ reproduction and also how we understand global governance. Thus factory profits are sustained via gendered discourses of work that relegate women to low wage, labourintensive export employment (see also Gunawardana in this volume) and forms of gender knowledge and expertise have fundamentally reshaped the way in which international institutions understand gender issues globally (see also Ferguson in this volume). The label feminist constructivism employed by Çağlar is of course a broad categorization, and there are interesting overlaps between this chapter and Griffin's chapter which seeks to understand the marginalization of poststructuralist feminist within IPE. Griffin is especially concerned by the way in which much critical IPE scholarship has simply ignored the insights of feminist IPE - in large part she suggests because feminist IPE, even that which has a more materialist orientation, ultimately points to the importance of social construction to the generation of gendered global inequalities. Discourse always matters in one way or another to feminist work - and to this end it cannot be easily accommodated within the Marxist or Neo-Gramscian IPE that dominates much critical IPE scholarship, especially in the UK context (see also Waylen 2006). Griffin warns that '[t]he distinction between the material/ideal in IPE is popular, but it is not natural'. Feminist IPE thus serves to destabilize such a binary and to this end, many scholars have found it easier to simply not engage with feminist work.

The discursive production of gender in the global political economy is also constituted by and through dominant ideas concerning sex and sexuality - and yet this insight is something that has only recently been taken up by feminist IPE scholars (notably, Bedford 2009; Lind 2010). Nicola Smith's chapter on queer theory and feminist political economy focuses on how these two fields have increasingly come to share common concerns as 'queer scholars are taking up struggles of economic and social justice as vital to those surrounding sexual justice' in ways that necessitate further engagement with feminist IPE work that takes as its starting point 'the complex intersections between intimacy and the economy in the study of global capitalism. Importantly, Smith's chapter raises methodological issues, asking how a queer feminist 


\section{Handbook on the international political economy of gender}

IPE might be done in ways that recognize the structures and hierarchies that shape sex industries while also recognizing the forms of transgression, agency and even radical political action that emerge out of struggles for sexual justice by sex workers.

How we might do feminist IPE is also taken up in the final chapter in this part by Georgina Waylen. Waylen asserts the need for a feminist institutionalist understanding of IPE - one in which the institutions of global governance, and, moreover, emerging networks and informal governance rules/clubs are imbued with gendered logics that have significant material effects. Gendering institutional analysis is about more than merely looking to how gender mainstreaming is done in certain organizational contexts, it is also about examining how the pervasive gendering of institutions takes shape in sites where gender politics are not asserted. Hegemonic masculinities are reproduced within powerful sites of the governance of the global economy and Waylen makes the case that more research needs to be done in order to investigate this. This will entail the kind of detailed empirical ethnographic fieldwork that many IPE scholars actively avoid, but which feminist researchers are frequently well equipped to undertake.

\section{Part II: Engagements and Perspectives}

The second part of the Handbook draws attention to some of the on-going engagements between feminist IPE and a range of other areas of study that are not always associated with this field of inquiry. Much of this engagement is not new, but is rather part of what helped to shape the current 'field' of feminist IPE in the ways noted above. For instance, chapters by Heidi Hudson, Jacqui True and Amanda Chisholm each, in their own way, draw attention to on-going engagements between feminist scholarship in IPE and feminist scholarship in Security Studies and IR more broadly. Offering a distinct take on current debates about the extent to which feminist IPE should (and already does) engage with this scholarship (Elias 2015; Roberts 2017), Hudson argues that rather than building fences around one's respective camp, feminists working in these areas should move from 'closed' to 'close' encounters. She argues that they should 're-invoke their interdisciplinary roots' in a way that allows them to look beyond simply re-asserting their importance to the field of IR and to position themselves in transdisciplinary terms, echoing moves in, for instance, Peace Studies, Postcolonial Studies, Women's Studies and Cultural Studies.

In her chapter on violence against women (VAW) in post-conflict settings, True shows how a feminist political economy method of analysis is necessary for helping to explain 'the continuum of gendered violence' in societies undergoing the transition from conflict to peace. In foregrounding how structural violence 'both intersects with as well as compounds the risks of physical violence', in addition to the impact that this has on women's political and economic participation, True demonstrates how such an analysis is integral to understanding the sorts of systemic changes that are needed to prevent and/or reduce the sexual and gender-based violence that affects women and girls as well as men and boys.

In her contribution, Chisholm brings feminist IPE into conversation with the literature on global militarism and private security companies. Surveying a wide range of studies, including her own ethnographic research on (Nepalese) Gurkha security 
contractors, Chisholm shows how a feminist IPE lens allows for a consideration of how security labour is managed, conditioned and disciplined - processes deeply embedded in colonial narratives of gender and race. For instance, security labourers from the Global North are seen as 'professional' whereas the labour of the Nepalese men is naturalized through colonial history and the logics of 'martial race'. Approaching the issue of private security from a feminist IPE perspective further opens the space to consider 'how women and their labour remain integral to the shaping of the security industry' through the 'labour of love' they provide for those working in high risk and highly flexibilized jobs. Taken together, these three chapters show that the silo-ing of feminist scholarship into areas that focus either on 'political economy' or 'security' (contested as these terms may be) greatly limits our ability to understand the complex nature of global politics as it is manifested from the macro to the micro scales. Hudson takes this point even further, explaining that the distinction between these areas of research is the product of Western academia, whereas there are bodies of gender research and activism in Africa, for instance, that defy this distinction altogether.

Chapters by Shirin Rai and Stefanie Wöhl also look back to some of the debates that have been central to the development of feminist IPE, including debates about global development, global governance and state theory. While, on the one hand, these interventions offer important summaries of those authors and ideas that have been incorporated into the 'common sense' of much feminist IPE, on the other, they also serve as important reminders that many of the issues with which contemporary feminist scholars are grappling are not new. As Rai stresses, many of the issues currently facing the Global North have been 'experienced, explored and theorized' in the context of the Global South, including issues related to austerity, the impact of ecological degradation and gendered conditions of labour. In her discussion of the state, Wöhl also draws links between contemporary processes designed to curtail the power of states to deviate from the neoliberal macroeconomic policies, such as the Fiscal Compact adopted by most members of the European Union (which compels them to maintain a deficit of 0.5 per cent or lower or risk sanctions) and the longer-standing attempts to compel such adherence by governments in the Global South, largely through Structural Adjustment Policies (SAPs) attached as conditions to loans provided by the International Financial Institutions (IFIs).

Both Rai and Wöhl point to the ways in which the unfolding of global capitalism has involved a dialectical relation between a series of processes at the global level, which have been supported by many of the advanced industrial states, and the everyday practices that take place within households and the local level. For example, as Rai notes, the price of food in the Global North 'makes sense only if we understand gendered global value chains'. This observation raises an important point, and one that has long been emphasized by feminist IPE scholars: everyday practices, which include practices of reproductive labour, lie at the heart of global capitalism; they are both shaped by and help to shape economies and how they are governed (for an overview see Elias and Roberts 2016). To put it differently, the 'mundane matters' (Enloe 2013) in understanding broader processes of global change. But while this has long been an insight of feminist work, recent debates within the broader field of IPE about 'the everyday' have tended to exclude feminist contributions. In her engagement with this literature, Stephanie Redden shows what is at stake in this exclusion. After surveying 
recent debates, she focuses specifically on Henri Lefebvre's influential three-volume Critique of Everyday Life, pointing to the deeply problematic dichotomy that Lefebvre creates between 'active' man and 'passive' women. However, while pointing to some of the limitations of this work, and that which seeks to re-centre it within IPE research, Redden ultimately believes that it offers valuable theoretical insights for feminist IPE scholars, particularly as it outlines potentials for transformation of the everyday.

The issue of transformation is one that is also raised by Catia Gregoratti, who takes as her starting point the recent resurgence of 'the business case' for gender equality and women's empowerment globally. While Gregoratti is sympathetic to some of the criticisms of the business case, which have come from feminist scholars working within various critical theoretical traditions, she points out that 'the business case is far from settled' as feminist organizations and movements are 'both resisting its everyday practices and, in some cases, proposing alternative, post-capitalist' models (see also McKinnon et al. in this volume). She argues that the insights of IPE scholars such as Robert Cox, who are attentive to contradictions and conflicts within global capitalism alongside the potentials for transforming global governance, need to be brought into the feminist research in this area. She illustrates this argument by looking at the Women's Empowerment Principles, which operate as a voluntary code of conduct for corporations, alongside several groups that have opposed this and other expressions of corporate social responsibility (CSR). Doing so helps to elucidate and to 'demystify corporate power and its effects on gendered lives', thus offering a more comprehensive and emancipatory way of theorizing how gender has been incorporated into global governance. In this sense, both Redden and Gregoratti offer important paths forward for feminist scholarship that emphasize human agency and the possibilities for collective action.

The final contribution in this part is by Victoria Pereyra Iraola, who advances an argument about the need for greater engagement between feminist IPE and the literature on imprisonment, which is mainly located in the fields of criminology and sociology (see also LeBaron and Roberts 2010; Roberts 2016). Where political economy has engaged with the issue of imprisonment, this has 'remained constricted by what might be termed a "male-biased" approach to incarceration' that views it primarily in relation to (paid) labour, and where 'the archetypal person affected by imprisonment is assumed to be a male individual'. This omission is important as criminalization and imprisonment affect not only staggering numbers of men, but also growing numbers of women, whose imprisonment is growing at a faster rate than that of men globally. As feminists have begun to show, processes associated with neoliberal restructuring that have led to the feminization of labour, the reduction of welfare budgets and the criminalization of women's survival strategies (such as sex work and drug trafficking) are fuelling the incarceration of women throughout the world. At the same time, Pereyra Iraola suggests that bringing feminist IPE perspectives to bear on this issue is needed to show how 'prisons permeate the daily lives of millions of women living in poverty', and transform gendered relations of paid and unpaid labour, potentially leading to a depletion of social reproductive capacities within poor and racialized communities. Thus, Pereyra Iraola opens up yet another potential research area ripe for exploration by feminist IPE scholars. 


\section{Part III: Governing Markets and Economies}

The third part of the Handbook explores some issues that may be more commonly associated with the field of IPE, including issues related to global governance, the role of IFIs, gender mainstreaming, the gendered dimensions of macroeconomic policymaking, microcredit and so on. However, they also show both how much knowledge feminist IPE has produced on these topics (some of which now have decades of research behind them) and how much work needs to be done to keep up with contemporary developments in the ways that markets and economies are being governed. This is very clearly demonstrated in Brigitte Young's chapter on the governance of finance, and particularly on central banking. As she suggests, despite the dominance of finance on a global scale, or 'financialization', feminist IPE has not paid sufficient attention to how monetary policies 'shape and structure gender relations across all levels of economic, political, social and cultural life'. Young then shows how the quantitative easing $(\mathrm{QE})$ policies, which have been pursued by many governments in Europe and elsewhere in the wake of 2008, lead to an 'asset bias' that results in highly unequal distributional outcomes to the detriment of women, the poor and certain racialized groups. As Roberts and Elias conclude in their overview of feminist research on financial crises, the current questioning of previous financial orthodoxies that has been engendered by the 2008 crisis opens a space for critical feminist reflection (i.e., on the gendered impacts on various forms of 'exceptional' monetary policy) and for the creation of alternative visions for the economy such as those that permeated discussions of the East Asian financial crisis (see also McKinnon et al. in this volume).

The contemporary status of microcredit as a cornerstone of anti-poverty and women's empowerment initiatives has also been cast into doubt in recent years. Whereas this was the development craze in the 1990s and 2000s, as Kenji Wada points out, we now have a clear body of research showing that in many instances, these projects may be doing more harm than good. Adopting a Foucauldian approach, Wada argues that rather than 'empowering' women to transform the social structures that produce their marginalization, microcredit reproduces power relations by essentializing women and transforming them into 'self-sufficient subjects' who must take on the burden of poverty reduction in the absence of state support. In making this argument, he highlights the ways in which microcredit supports the broader neoliberal project by legitimizing a diminished role of the state and transforming women and the poor into entrepreneurial subjects who, with the proper self-discipline, should be able to succeed in increasingly liberalized market economies.

Rahel Kunz similarly shows how the so-called 'feminization of migration' has led to a narrative on the part of global governance institutions that portrays women as being better at sending home their remittances (or foreign earnings) than men, and therefore the 'new development agents par excellence'. Among other problems, Kunz finds that this discourse essentializes women and men - assuming that the former are more strongly motivated by altruism whereas the latter are more self-interested - while also working to invisibilize all of the productive and reproductive work that is carried out by non-migrants in receiving societies. At the same time, like microcredit, remittances have been positioned as key to enabling families to lift themselves out of poverty (and to alleviate the negative impacts of the most recent economic crisis) in the absence of 
state support, legitimizing the neoliberal vision of the state and failing to challenge the sorts of macroeconomic policies that have perpetuated poverty and inequality globally.

Kunz further links remittance policies to broader processes that have aimed to bring women and the global poor into financial relations through financial inclusion strategies and processes of financialization. In their overview of feminist research on global financial crises from the 1980s to the present, Adrienne Roberts and Juanita Elias show how, despite being excluded from many forms of formal finance, the operation of global finance both draws upon and affects women, gender relations and relations of social reproduction. 'While many assume that finance is a sphere of objectivity and gender-neutrality', feminist scholars have argued that this is in fact rooted in a particular masculinized view of economics that devalues and/or ignores a whole host of activities and behaviours that constitute the social relations of finance. In contrast to the gender blind writing on financial crises, which tend to focus on the effects of crises on economic growth, feminist scholarship has shown how they affect men and women, as well as gender norms of behaviour, in the productive, reproductive and financial spheres. It has also shown how the gendered representation of crises may work to depoliticize crises (which are seen to be 'temporary interruptions in an otherwise smooth functioning capitalism') and to perpetuate gendered myths about how positioning women at the head of financial institutions can 'clean up' the morally dubious practices of global financial firms. Again, at issue here is how these representations work to shift attention away from challenges to the operation of global capitalism (Hozic and True 2016).

Gendered myths about women as 'saviours' of national economies and global economic growth are also explored in chapters by Sydney Calkin and Sara Wallin on the World Bank and the European Bank for Reconstruction and Development (EBRD), respectively. As Calkin argues, '[d]espite its somewhat troubled history with gender mainstreaming', the World Bank today positions itself as a leader in gender and development knowledge and best practice. However, the prominence of gender in the World Bank presents somewhat of a dilemma for feminist IPE scholars, as it represents, on the one hand, the hard-won gains of decades of feminist activism and research, and, on the other, the incorporation of this activism and research into an agenda that is firmly compatible with neoliberalism while ignoring some of the more radical transformative aspects of the feminist critique (see also Gregoratti in this volume). 'As such,' Calkin suggests, 'the World Bank presents an ideal site of analysis to address the long-standing debate about the extent to which feminist change can be achieved through gender mainstreaming in dominant institutions.' This question of the possibilities of gender mainstreaming within IFIs is precisely what Wallin seeks to answer in her chapter on the EBRD. The conclusion she draws is that 'gender mainstreaming operates as a governance strategy at the EBRD, which aims to extend and deepen marketization by adding women [to its existing mandate of promoting the extension of capitalist markets into Eastern Europe and elsewhere] and embedding entrepreneurship and employment into gendered social relations'.

While noting that the EBRD has adopted a language (and policy) of gender equality that ultimately fails to 'subvert or challenge the structures that contribute to women's inequality', Wallin also takes care to show the difficulties faced by the staff working on these issues, who were forced to work under particular constraints while recognizing 
the limitations of such an approach. The intricacies of negotiating gender aware policies within institutions is the focus of Lucy Ferguson's chapter on gender expertise. Noting the growing demand for experts and trainers to support the implementation of gender mainstreaming, Ferguson thinks it is unsurprising that many feminist scholars find 'the marketization and professionalization of gender and feminist knowledge' to be problematic. However, she presents a challenge to critics who understand gender experts solely in terms of their role in 'legitimating and embedding neoliberal visions of development', which she finds to be 'limiting and constraining, and do not allow space for feminist politics and action'. Drawing on the voices and reflections of practitioners and 'outsider' academics, Ferguson seeks to emphasize the politics and resistances of gender experts, bringing to light the 'micro processes of negotiation in which gender experts are constantly engaging' and showing how practitioners manage to navigate the constraints of increasingly technocratic frameworks. In doing so, she offers an important challenge to those critics of the turn towards the 'business case' for gender equality, including many of those represented in this volume.

Finally, another challenge to many of the assumptions underlying chapters in this volume is raised by Katharine McKinnon, Kelly Dombroski and Oona Morrow's chapter on alternative economies. McKinnon et al. approach their chapter from the perspective of feminist economic geography, and from their position as members of the 'Community Economies Collective' and the 'Community Economies Research Network', which are 'international collaborative networks of researchers who share an interest in theorizing, discussing, representing and ultimately enacting new visions of economy'. Building on the work of J.K. Gibson-Graham and others, this chapter questions how we conceptualize 'the economy' and problematizes the tendency for many scholars (including feminist scholars) to assume the dominance of global capitalism in multiple spheres of life. They argue that in conflating 'the economy' with global capitalism, scholars strengthen the dominance, naturalness and inevitability of global capitalism while diminishing 'the worth of other ways of making livelihoods'. Even analyses that focus on social reproduction, they argue, ultimately fail to 'adequately capture the productivity and heterogeneity of household labour', and leave many economic interactions unexplored. Instead, this chapter outlines an alternative framework for conceptualizing the economy 'in its already existing multiplicity and diversity', with the aim of 'queering' capitalism and making non-capitalist possibilities more substantial and definitive. Surveying examples of emerging work that focuses on community economies of the kind that they wish to foster, McKinnon et al. show how we can analyse and enact new visions of economy, which is central for building post-capitalist futures.

\section{Part IV: The Political Economy of People and Things}

The final part of this Handbook concerns the emergence of gendered global markets which have been accompanied by circulations of people and things alongside global flows of capital. Many of these chapters focus on this concern via an exploration of the gendered impacts of global commodity and migratory flows. At the same time, many of the chapters draw attention to how gender plays an important role in contemporary forms of enclosure, commodification and marketization - processes that have facilitated 


\section{Handbook on the international political economy of gender}

the widening and deepening of the market into everyday spaces and routines, households and bodily practices.

In line with a large swathe of current feminist political economy research, a core concern of many of the chapters in this part takes up the issue of the commodification of care and caring relations. As the chapter by Tiina Vaittinen, Hanna-Kaisa Hoppania and Olli Karsio points out, turning care into a commodity leads to a fundamental and qualitative reconstitution of the very understanding of what care is. Hironori Onuki's chapter picks out another dimension of care work within the current neoliberal order the ways in which care work is always incompletely commodified because of its association with female household labour seen as operating outside of the productive sphere. In both chapters the commodification of care and the emergence of global markets for care work are understood in relation to forms of state restructuring. Large cuts to state spending in Nordic countries, for example, are shown in the chapter by Vaittinen et al. to have led to an increased reliance on privatized services in which care recipients are transformed from 'a citizen with care needs into a consumer of care services' and thus serving to transform notions of citizenship rooted in ideas of collective responsibility. Onuki draws upon examples from Asia to illustrate the role of the state in the growing market for care work, for example, via the inclusion of quotas for care workers in a trade agreement between Japan and the Philippines. For Onuki this trade agreement represents an illustration of 'how economic agreements among states now govern not only the realms of production, trade and investment, but also increasingly those of social reproduction'. The state and, in particular, state bordering practices, is discussed further in Sedef Arat-Koç's chapter on forced (domestic) labour. This chapter considers how domestic and care work that operates in relation to exclusionary border regimes comes to constitute a key form of feminized unfree labour. Arat-Koç draws upon the case of Canada in order to illustrate how the conditions of unfreedom are reproduced even in national settings that are considered to have somewhat more benign and/or progressive migration regimes.

Also looking to the issue of migration, Eleonore Kofman and Parvati Raghuram suggest that the important focus on care and care chains in feminist IPE work has somewhat overshadowed work on migration. Bringing a concern with social reproduction into feminist studies of migration also necessitates looking beyond the emergence of care markets. Rather than looking to female migrants as merely filling care 'gaps', we also need to think about how 'the failure and/or inadequate conditions of social reproduction are not only an outcome but also a driver of global migrations' - including migrations by groups who are not the usual focus of feminist IPE analysis (e.g., refugees, students, family migrants and labour migrants not employed in care industries; see also chapters by Gunawardana and LeBaron in this volume).

Similarly, Genevieve LeBaron's chapter also makes the case for expanding the empirical focus of feminist IPE. Her chapter engages with the issue of unfree labour with a specific focus on the relatively understudied issue of women's unfree labour in global commodity chains. An emerging IPE literature on unfree labour in global supply chains has started to raise important criticisms of a dominant 'modern day slavery' perspective in which worker's agency and identity is obscured via a sensationalist focus on the very worst forms of oppressive labour exploitation. LeBaron calls for an IPE approach to unfree labour that thoroughly investigates the causes and consequences of 
unfreedom, challenges the view that there can ever be acceptable/normal forms of worker exploitation, and recognizes the centrality of gender to the category of unfree labour: 'there are urgent and unresolved empirical questions about why, when, where and how women are more vulnerable to unfree labour than men'.

Studies of female factory work have long been an important preoccupation for feminist IPE scholars. Feminist theorists of globalization, for example, have pointed to the mass feminization of export industrialization that occurred from the 1970s onwards as light manufacturing industries moved to locations in the Global South. Samanthi J. Gunawardana's chapter considers these debates and then moves to consider how feminized factory work is changing - honing in on how narratives of female 'empowerment' and emancipation via factory work are mobilized in ways that present the expansion of factory work as a panacea for many problems faced by women today. This includes the rise of a pervasive neoliberal logic that sees the needs of victims of forced displacement and/or trafficking as best met via their incorporation into global commodity chains. Studies of factory work and women's migration certainly serve to highlight the possibilities and opportunities that engagement in the market economy opens up for marginalized groups (such as young women from some of the most economically marginalized regions of the world), and they also highlight the structural (and at times, more direct) forms of violence so central to the expansion of markets that uphold systems of low wage labour.

As Zoe Pflaeger Young shows in her chapter, long-standing feminist accounts of the gender politics of international trade have pointed to the relationships between women's low wage employment and the expansion of export industrialization. Pflaeger Young provides numerous examples of the ways through which international trade rules disadvantage women, themes that also come through strongly in chapters by Merisa Thompson and Angela McCracken that respectively consider how global markets for food and beauty are gendered. Food and beauty are also commodities and industries that have generated a great deal of feminist work - most of which has not been produced by IPE scholars. What these two chapters have in common, then, is that by looking to wide-ranging interdisciplinary literatures, they are able to point to new issues and agendas for the study of IPE - including a more sustained focus on consumption practices, everyday experiences of women's agency and industry-specific yet deeply gendered and racialized labour practices. Thompson thus points out how a feminist approach provides key insights into the gendered nature of food production and food consumption. A critical gender analysis exposes the feminized labour relations involved in food production in both the site of market and non-market production as well as the relationship between food and social reproduction. These are findings that tend to be overlooked by scholars of the global food system who have largely focused on issues of 'food security' and 'food sovereignty' in a gender blind manner.

While also focused on the gendered nexuses between production, social reproduction and consumption, McCracken's chapter on Beauty also raises important issues about agency within the context of globalization. Women's role within the beauty industry cannot simply be understood in terms of the imposition of patriarchal and racist beauty standards - we also need to understand how women 'are primary agents for the development of beauty industries and their globalization' while also recognizing how 
'the global political economy of beauty is shaping the images, ideals and practices of beautification, indeed, shaping the body'.

Sara Kallock's chapter raises some parallel themes to McCracken's, highlighting the entrenched divides that exist within feminist understandings of the emergence of global markets for sex work. Feminist IPE work on this issue has often started from the acknowledgement of competing (liberal and radical) feminist positions on sex work before moving to articulate a rather more 'ambivalent' 'sex labourism' perspective in which sex work operates within exploitative structures of global capitalism and yet at the same time exerts agency and disrupts moral orders. Kallock shows how all three perspectives inform the ethical terrain within which sex work is understood and draws upon examples from her own research into frontline sex services in the north of England to illustrate this point.

The final part of this volume showcases not only the ever widening empirical remit of feminist IPE but also its theoretical pluralism and even, at times, eclecticism. Social reproduction feminism in the work of Arat-Koç, Kofman and Raghuram, and Onuki is thus complemented by work that takes a more poststructuralist, cultural political economy or postcolonial feminist approach in the chapters by McCracken, Thompson and Kallock. In this sense, this part showcases the richness and diversity of feminist IPE. Nonetheless, it should be noted that what all of the chapters in this part serve to illustrate is the persistence of poverty and its importance in shaping economic flows of people and things and the gendered and racialized forms of inequality and oppression that are at work in global markets.

\section{CONCLUSION}

The following 34 chapters of this Handbook show that as a field of research, feminist IPE is thriving. While some of the approaches and empirical topics addressed by scholars who identify themselves with feminist IPE are familiar, and have long been at the forefront of IPE research (including topics related to the gendered nature of markets, labour regimes and global economic governance), others open new and exciting areas for feminist theory and research. The vast range of scholarship documented in these pages shows the complex and contradictory ways in which gender operates in and through the plethora of diverse structures, social relations and discursive practices that constitute the contemporary global political economy. While it would be beyond the scope of any volume to fully capture these dynamics, we believe that this collection goes further than any other published to date in documenting the value of feminist approaches to IPE.

Of course, there are also limitations to volumes such as this, which will necessarily produce the exclusion (and/or under-representation) of particular viewpoints and issue areas. Future collections of this sort would do well to better include, for instance, different feminist perspectives on the environment and climate change, on global health, and on forced displacement and refugees. There is also room to more fully document feminist IPE engagement with the disciplines of human geography, legal studies, anthropology, Black and Indigenous studies and more. While the research featured in the volume focuses on the Global South as well as the Global North we also 
acknowledge that the majority of authors are based in institutions in North America, Europe and Australia. This is partly the result of broader power relations at work in the academy, which shape academic networks and draw many scholars from the Global South to these relatively well-funded and internationally reputed centres of academic knowledge production. At the same time, many of the conferences and workshops that feature feminist IPE research are held exclusively in English, involve costly registration fees, and are held in Western countries where travel is expensive and has been made increasingly difficult if not prohibitive by racist migration and refugee policies. ${ }^{6}$ As Hudson documents in her chapter, there are also places where the framework of feminist IPE, and presumably other forms of IPE as well, do not fit comfortably with locally produced knowledge and activism.

The point of raising these limitations is to again stress the shortcomings of any attempt to fully capture a field of study, and to reiterate the point that this volume should not be viewed as a boundary-drawing exercise. In contrast, we have surveyed existing scholarship with the aim of helping to further broaden the scope of feminist IPE research.

\section{NOTES}

1. Recent feminist IPE monographs include Calkin (2018), Roberts (2016), Meger (2016), Chin (2013), McCracken (2014), True (2012), Kunz (2011), Griffin (2009).

2. Rowley and Shepherd's examination of IR teaching and core textbooks suggested that there is a tendency to 'caricature' gendered International Relations (IR) and to treat gender as a synonym for women (2012, p. 154). Invariably very similar practices are at work within IPE teaching and textbooks as well - although a comprehensive survey of this nature has not yet been undertaken (see also Childs and Krook 2006 for a survey of political science texts that points to the minimal coverage of gender issues and/or feminism). It should be noted that a number of IPE texts (we include here core teaching textbooks and works designed to chart the field that are used extensively in teaching) include either scant mention of women/feminism/gender (e.g., see Held et al. 1999; Gilpin 2001; Cohn 2003; Lairson and Skidmore 2003; Phillips 2005; Ravenhill 2016) or confine 'gender issues' to a single chapter (e.g., see Rupert and Soloman 2005; Cafruny et al. 2016). Of course, there do also exist texts that cover gender issues extensively or from multiple perspectives (see, e.g., Stubbs and Underhill 2005; Paul and Amawi 2013; O’Brien and Williams 2016).

3. See Hudson's chapter in this volume for an in-depth overview of some of the tensions and convergences between feminist IPE and IR scholarship.

4. It should be noted that Jaquette's chapter does not engage with the neoliberal feminist thought of transnational business feminists such as Sheryl Sandberg or the invocation of (liberal) feminist norms within institutions of global governance such as the World Bank.

5. Although, as Stone (2007, p. 200) suggests, an alternative approach is the suggestion that equality in the public sphere can only be attained once the public realm is itself 'feminized'.

6. For example, at the 2017 International Studies Association conference held in Baltimore, USA, a number of academics from predominantly Muslim countries and others were forced and/or chose to withdraw from proceedings as the result of President Donald Trump's attempts to impose a ban on Muslims from entering the country and the forms of profiling and harassment that were legitimized by these attempts. 


\section{Handbook on the international political economy of gender}

\section{REFERENCES}

Ackerly, B. and J. True (2010), Doing Feminist Research in Political \& Social Science. Houndmills, Basingstoke: Palgrave Macmillan.

Ackerly, B. and J. True (2013), 'Methods and Methodologies', in Georgina Waylen (ed.), The Oxford Handbook of Gender and Politics. New York: Oxford University Press, pp. 135-59.

Bakker, I. and S. Gill (2003), 'Global Political Economy and Social Reproduction', in Isabella Bakker and Stephen Gill (eds), Power, Production and Social Reproduction: Human In/Security in the Global Political Economy. Basingstoke: Palgrave Macmillan, pp. 3-41.

Bakker, I. and R. Silvey (eds) (2008), Beyond States and Markets: The Challenges of Social Reproduction. London: Routledge.

Bedford, K. (2009), Developing Partnerships: Gender, Sexuality and the Reformed World Bank. Minneapolis, MN: University of Minnesota Press.

Bedford, K. and S. Rai (2010), 'Feminists Theorize the International Political Economy', Signs 36 (1), $1-18$.

Bergeron, Suzanne (2003), Fragments of Development: Nation, Gender and the Space of Modernity. Ann Arbor, MI: University of Michigan Press.

Bernstein, E. (2014), 'Introduction: Sexual Economies and New Regimes of Governance', Social Politics 21 (3), 345-54.

Bezanson, K. and M. Luxton (eds) (2006), Social Reproduction: Feminist Political Economy Challenges Neo-liberalism. Montreal-Kingston: McGill-Queens University Press.

Blyth, M. (ed.) (2009), Routledge Handbook of International Political Economy (IPE): IPE as a Global Conversation. London: Routledge.

Cafruny, A., L.S. Talani and G. Pozo Martin (eds) (2016), The Palgrave Handbook of Critical International Political Economy. London: Palgrave Macmillan.

Calkin, S. (2018), Human Capital in Gender and Development: Feminist Political Economy and Empowerment. London: Routledge.

Childs, S. and M.L. Krook (2006), 'Gender and Politics: The State of the Art', Politics 26 (1), 18-28.

Chin, C.B.N. (2013), Cosmopolitan Sex Workers: Women and Migration in the Global City. Oxford: Oxford University Press.

Cohen, B. (2007), 'The Transatlantic Divide: Why are American and British IPE So Different?', Review of International Political Economy 14 (2), 197-219.

Cohen, B. (2008), International Political Economy: An Intellectual History. Princeton, NJ: Princeton University Press.

Cohn, T.H. (2003), Global Political Economy: Theory and Practice, second edn. New York: Longman.

Connell, R. (1995), Masculinities. Berkeley, CA: University of California Press.

Cook, J., J. Roberts and G. Waylen (eds) (2000), Towards a Gendered Political Economy. Basingstoke: Palgrave Macmillan.

Cox, Robert W. (1987), Production, Power and World Order: Social Forces in the Making of History. New York: Columbia University Press.

Davis, A. (1981), Women, Race and Class. London: Random House.

Edholm, F., O. Harris and K. Young (1978), 'Conceptualizing Women', Critique of Anthropology 3 (9-10), 101-30.

Elias, J. (2011), 'Critical Feminist Scholarship and IPE', in Stuart Shields, Ian Bruff and Huw Macartney (eds), Critical International Political Economy: Dialogue, Debate and Dissensus. Houndmills, Basingstoke: Palgrave Macmillan, pp. 99-116.

Elias, J. (2015), 'Introduction: Feminist Security Studies and Feminist Political Economy: Crossing Divides and Rebuilding Bridges', Politics \& Gender 11 (2), 406-8.

Elias, J. and A. Roberts (2016), 'Feminist Global Political Economies of the Everyday: From Bananas to Bingo', Globalizations 13 (6), 787-800.

Enloe, C. (1989), Bananas, Beaches and Basis: Making Feminist Sense of International Politics. London: Pandora.

Enloe, C. (2013), Seriously! Investigating Crashes and Crises as If Women Mattered. Berkeley, CA: University of California Press.

Ferber, M.A. and J. Nelson (1993), Beyond Economic Man: Feminist Theory and Economics. Chicago, IL: University of Chicago Press. 
Ferguson, S., G. LeBaron, A. Dimitrakaki and S.A. Farris (2016), 'Introduction: Special Issue on Social Reproduction', Historical Materialism 24 (2), 25-37.

Folbre, N. (1995), “Holding Hands at Midnight”: The Paradox of Caring Labour', Feminist Economics 1 (1), 73-92.

Gilpin, R. (2001), Global Political Economy: Understanding the International Economic Order. Princeton, NJ: Princeton University Press.

Griffin, P. (2009) Gendering the World Bank: Neoliberalism and the Gendered Foundations of Global Governance. London: Palgrave MacMillan.

Hartmann, H. (1979), 'The Unhappy Marriage of Marxism and Feminism: Towards a More Progressive Union', Capital \& Class 3 (2), 1-33.

Held, D., A. McGrew, D. Goldblatt and J. Perraton (1999), Global Transformations: Politics, Economics and Culture. Cambridge: Polity.

Hemmings, C. (2011), Why Stories Matter: The Political Grammar of Feminist Theory. Durham, NC: Duke University Press.

hooks, b (2000), Where we Stand: Class Matters. New York: Routledge.

Hozic, A. and J. True (eds) (2016), Scandalous Economics: Gender and the Politics and Financial Crisis. Oxford: Oxford University Press.

Jackson, C. and R. Pearson (1998), Feminist Visions of Development: Gender Analysis and Policy. London: Routledge.

Jordan, R., D. Maliniak, A. Oakes, S. Peterson and M.J. Tierney (2009), One Discipline or Many? TRIP Survey of International Relations in Ten Countries. Report, Institute for the Theory and Practice of International Relations, College of William and Mary, February.

Kabeer, N. (1994), Reversed Realities: Gender Hierarchies in Development Thought. London: Verso.

Kunz, R. (2011), The Political Economy of Global Remittances: Gender, Governmentality and Neoliberalism. London: Routledge.

Lairson, T.D. and D. Skidmore (2003), International Political Economy: The Struggle for Power and Wealth. Belmont, CA: Thomson/Wadsworth.

Laslett, B. and J. Brenner (1989), 'Gender and Social Reproduction: Historical Perspectives', Annual Review of Sociology 15 (3), 381-404.

LeBaron, G. and A. Roberts (2010), 'Toward a Feminist Political Economy of Capitalism and Carcerality', Signs 36 (1), 19-44.

Lind, A. (ed.) (2010), Development, Sexual Rights and Global Governance. London: Routledge.

Locher, B. and E. Prügl (2001), 'Feminism and Constructivism: Worlds Apart or Sharing the Middle Ground?', International Studies Quarterly 45 (1), 111-29.

Marchand, M. and J. Parpart (eds) (1995), Feminism/Postmodernism/Development. New York: Routledge.

Marchand, M.H. and A.S. Runyan (2000), 'Introduction: Feminist Sightings of Global Restructuring: Old and New Conceptualizations', in M.H. Marchand and A.S. Runyan (eds), Gender and Global Restructuring: Sightings, Sites and Resistances. Reprinted in 2011, London: Routledge, pp. 1-24.

McCracken, A.B. (2014), The Beauty Trade: Youth Gender and Fashion Globalization. Oxford: Oxford University Press.

Meger, S. (2016), Rape Loot Pillage: The Political Economy of Sexual Violence in Armed Conflict. Oxford: Oxford University Press.

Moghadam, V.M. (2005), Globalizing Women: Transnational Feminist Networks. Baltimore, MD: John Hopkins University Press.

Mohanty, C.T. (2003), "Under Western Eyes" Revisited: Feminist Solidarity Through Anti-capitalist Struggles', Signs 28 (2), 499-535.

Murphy, C. and D. Nelson (2001), 'International Political Economy: A Tale of Two Heterodoxies', British Journal of Politics and International Relations 3 (3), 393-412.

Nicholson, L. (1994), 'Interpreting Gender', Signs 20 (1), 79-105.

O'Brien, R. and Marc Williams (2016), Global Political Economy: Evolution and Dynamics, fifth edn. London: Palgrave Macmillan.

Paul, D.E. and A. Amawi (eds) (2013), The Theoretical Evolution of International Political Economy: A Reader. Oxford: Oxford University Press.

Peterson, V.S. (2002), 'Rewriting (Global) Political Economy as Reproductive, Productive, and Virtual (Focauldian) Economies', International Feminist Journal of Politics 4 (1), 1-30.

Peterson, V.S. (2003), A Critical Rewriting of Global Political Economy: Interrogating Reproductive, Productive and Virtual Economies. London: Routledge.

Peterson, V.S. and A.S. Runyan (1999), Global Gender Issues, second edn. Boulder, CO: Westview Press. 


\section{Handbook on the international political economy of gender}

Pettman, J.J. (1996), Worlding Women: A Feminist International Politics. London: Routledge.

Phillips, N. (ed.) (2005), Globalizing International Political Economy. Houndmills, Basingstoke: Palgrave Macmillan.

Rai, S. (2002), Gender and the Political Economy of Development. Cambridge: Polity.

Rai, S. and G. Waylen (eds) (2013), New Frontiers in Feminist Political Economy. London: Routledge.

Ravenhill, J. (2016), Global Political Economy, fifth edn. Oxford: Oxford University Press.

Roberts, A. (2016), Gendered States of Punishment and Welfare: Feminist Political Economy, Primitive Accumulation and the Law. London: Routledge.

Roberts, A. (2017), 'The Future of Feminist International Relations', in Synne L. Dyvik, Jan Selby and Rorden Wilkinson (eds), What's the Point of International Relations? Abindgon and New York: Routledge, pp. 231-41.

Rowley, C. and L. Shepherd (2012), 'Contemporary Politics: Using the "F" Word and Teaching Gender in International Relations', in C. Gormley-Heenan and S. Lightfoot (eds), Teaching Politics and International Relations. Houndmills, Basingstoke: Palgrave Macmillan, pp. 146-62.

Rupert, M. and M.S. Soloman (2005), Globalization and International Political Economy: The Politics of Alternative Futures. Lanham, MD: Rowman \& Littlefield.

Salem, S. (2018), 'On Transnational Feminist Solidarity: The Case of Angela Davies in Egypt', Signs 43 (2), pp. 245-67.

Sen, G. and C. Grown (1987), Development, Crises and Alternative Visions. London: Earthscan.

Shepherd, L. and L. Ferguson (2011), 'Gender, Governance and Power: Finding the Global at the Local Level', Globalizations 8 (2), 127-33.

Steans, J. (2003), 'Engaging from the Margins: Feminist Encounters with the Mainstream of International Relations', British Journal of Politics and International Relations 5 (3), 428-54.

Steans, J. (2013), Gender and International Relations, third edn. London: Polity Press.

Steans, J. and D. Tepe (2010), 'Introduction - Social Reproduction in International Political Economy: Theoretical Insights and International, Transnational and Local Sitings', Review of International Political Economy 17 (5), 807-15.

Stone, A. (2007), An Introduction to Feminist Philosophy. Cambridge: Polity.

Stubbs, R. and Geoffrey R.D. Underhill (eds) (2005), Political Economy and the Changing Global Order, third edn. Oxford: Oxford University Press.

Tepe-Belfrage, D. and S. Wallin (2016), 'Austerity and the Hidden Costs of Recovery: Inequality and Insecurity in UK Households', British Politics 11 (4), 389-95.

Tickner, A.J. (1991), 'On the Fringes of the World Economy: A Feminist Perspective', in Craig N. Murphy and Roger Tooze (eds), The New International Political Economy. Boulder. CO: Lynne Reiner, pp. 191-206.

Tickner, A.J. (1997), 'You Just Don't Understand: Troubled Engagements Between Feminists and IR Theorists', International Studies Quarterly 41 (4), 611-32.

True, J. (2012), The Political Economy of Violence Against Women. Oxford: Oxford University Press.

Vogel, L. (1983), Marxism and the Oppression of Women: Towards a Unitary Theory. New Brunswick, NJ: Rutgers University Press.

Waylen, G. (2006), 'You Still Don't Understand: Why Troubled Engagements Continue Between Feminists and (Critical) IPE', Review of International Studies 32 (1), 145-64.

Widmaier, W. (2015), 'Lawyers, Gender and Money: Consensus, Closure and Conflict in the Global Financial Crisis', Politics and Gender 11 (2), 265-90.

Zalewski, M. (2000), Feminism After Postmodernism: Theorizing Through Practice. London: Routledge.

Zalewski, M. (2007), 'Do We Understand Each Other Yet? Troubling Feminist Encounters With(in) International Relations', British Journal of Politics and International Relations 9 (2), 302-12. 